\title{
RISEARCA IIS SPOOM PHYSICALAC MIN \\ Mood states and cytokine correlation in female soccer players with and without premenstrual syndrome (PMS)
}
Autor(es): Junior, Luiz Antonio Luna; Bachi, André Luis Lacerda; Martins, Marcia Aparecida; Vieira, Rodolfo de Paula; Araújo, Maíta Poli; Parmigiano, Tatiana Rebizzi; Di-Bella, Zsuzsanna Ilona Katalin de Jármy

Foster, Roberta; Vaisberg, Mauro; Santos, Juliana de Melo Batista dos;

Publicado por: Imprensa da Universidade de Coimbra

URL persistente:

URI:http://hdl.handle.net/10316.2/44135

DOI:

DOI:https://doi.org/10.14195/2182-7087_ex2018_72

Accessed :

$$
\text { 26-Apr-2023 14:36:51 }
$$

A navegação consulta e descarregamento dos títulos inseridos nas Bibliotecas Digitais UC Digitalis, UC Pombalina e UC Impactum, pressupõem a aceitação plena e sem reservas dos Termos e Condições de Uso destas Bibliotecas Digitais, disponíveis em https://digitalis.uc.pt/pt-pt/termos.

Conforme exposto nos referidos Termos e Condições de Uso, o descarregamento de títulos de acesso restrito requer uma licença válida de autorização devendo o utilizador aceder ao(s) documento(s) a partir de um endereço de IP da instituição detentora da supramencionada licença.

Ao utilizador é apenas permitido o descarregamento para uso pessoal, pelo que o emprego do(s) título(s) descarregado(s) para outro fim, designadamente comercial, carece de autorização do respetivo autor ou editor da obra.

Na medida em que todas as obras da UC Digitalis se encontram protegidas pelo Código do Direito de Autor e Direitos Conexos e demais legislação aplicável, toda a cópia, parcial ou total, deste documento, nos casos em que é legalmente admitida, deverá conter ou fazer-se acompanhar por este aviso. 


\section{ANNALS OF RESEARCH IN SPORT AND PHYSICAL ACTIVITY}




\section{MOOD STATES AND CYTOKINE CORRELATION IN FEMALE SOCCER PLAYERS WITH AND WITHOUT PREMENSTRUAL SYNDROME (PMS)}

Roberta Foster ${ }^{1}$; Mauro Vaisberg ${ }^{2}$; Juliana de Melo Batista dos Santos ${ }^{2}$; Luiz Antonio Luna Junior²; André Luis Lacerda Bachi3; Marcia Aparecida Martins²; Rodolfo de Paula Vieira4; Maíta Poli Araújoz; Tatiana Rebizzi Parmigiano2; Zsuzsanna llona Katalin de Jármy Di-Bella²

Keywords: inflammation, cytokines, mood states, Premenstrual syndrome, soccer

\section{INTRODUCTION}

PMS is defined as a group of physical and behavioral changes beginning in the luteal phase and ending during menstruation ${ }^{(1)}$. It's known that intense physical activity is closely associated with changes in many aspects of immune response, such as cytokine production $^{(2)}$ as well as that cytokines act on behavior and mood states (3-5). The aim of this study was to evaluate mood states and its relation with cytokine production in female soccer players with (PMS) and without PMS (nPMS) in 4 moments: before and after the game and in the two phases of the menstrual cycle: follicular and luteal.

\section{METHODS}

Fifty-two eumenorreic soccer players were evaluated (age:19.8 \pm 4.7 years). The PMS and phases of the menstrual cycle were determined by monitoring for 3 consecu-

\footnotetext{
1 Nove de Julho University (UNINOVE) / Federal University of São Paulo (UNIFESP).

2 Federal University of São Paulo (UNIFESP).

3 Cruzeiro do Sul University (UNICSUL).

${ }^{4}$ Nove de Julho University (UNINOVE).

Email: robertafoster@ig.com.br
} 
tive months. Evaluation of cytokines IL-1 $\beta$, IL- 6, IL- $-8, I L-10$ and TNF- $\alpha$ were performed in urine and quantified by Flow cytometry method. The renal function was normal, as could be verified through creatinine analysis. Mood states were evaluated through the Brunel mood scale. This study was approved by the Ethics Committee in Research, from UNIFESP (No.1604/10). ANOVA and Spearman correlation with significance level of 5\% were used for data analysis.

\section{RESULTS}

No difference in renal function was found in both groups and in the 4 evaluated moments. The group nPMS showed a positive correlation of IL-10 with vigor $(p=0,05, r=0,45)$ and a negative correlation of IL-10 with fatigue $(p=0,05, r=-0,45)$ in luteal phase, pregame. The PMS group revealed positive correlations of IL-1 $\beta$ in the follicular phase, postgame with anger $(p=0,05, r=0,37)$ and tension $(p=0,01, r=0,52)$; as well as the IL-1 $\beta$ with tension $(p=0,05, r=0,36)$ in the luteal phase, post-game.

\section{DISCUSSION}

The correlation observed in the group nPMS reveals that IL-10 has a positive correlation with vigor. Moreover, the IL-1 $\beta$ may contribute to the worsening of anger and tension behavioral states in the group PMS. In addition, our group has demonstrated that athletes with PMS are affected by an inflammatory state with higher levels of pro-inflammatory cytokines production.

\section{CONCLUSION}

The results observed in this study show that the anti-inflammatory cytokine is correlated with the emotion considered positive in the nPMS athletes, while the considered negative emotions are shown to be correlated with pro-inflammatory cytokine in the PMS athletes, reinforcing that the expression of different emotions in sport environment can be influenced by neuro-immuno-endocrine mechanism. 


\section{ACKNOWLEDGEMENT:}

Sao Paulo Research Foundation (FAPESP).

\section{REFERENCES:}

1. Usman, S. B., Indusekhar, R., \& O'Brien, S. (2008). Hormonal management of premenstrual syndrome. Best Pract Res Clin Obstet Gynaecol, 22(2), 251-260.

2. Gleeson, M. (2007). Immune function in sport and exercise. J Appl Physiol, 103(2), 693-699.

3. Bachi, A. L., Rios, F. J., Vaisberg, P. H., Martins, M., de Sa, M. C., Victorino, A. B., . . Vaisberg, M. (2015). Neuro-immuno-endocrine modulation in marathon runners. Neuroimmunomodulation, $22^{(3)}, 196-$ 202.

4. Pesce, M., Speranza, L., Franceschelli, S., Ialenti, V., lezzi, I., Patruno, A., ... \& Grilli, A. (2013). Positive Correlation Between Serum Interleukin-1 $\beta$ and State Anger in Rugby Athletes. Aggressive behavior, 39(2), 141-148.

5. Pesce, M., Fratta, I. L., Ialenti, V., Patruno, A., Ferrone, A., Franceschelli, S., . . Grilli, A. (2015). Emotions, immunity and sport: Winner and loser athlete's profile of fighting sport. Brain Behav Immun, 46, 261269. 